\title{
Beyond Radicalism and Resignation: The Competing Logics for Public Participation in Policy Decisions
}

\author{
Rikki Dean
}

\section{Contents}

1. Introduction ..................................................................................... 4

2. Existing Typologies of Participation.......................................................... 6

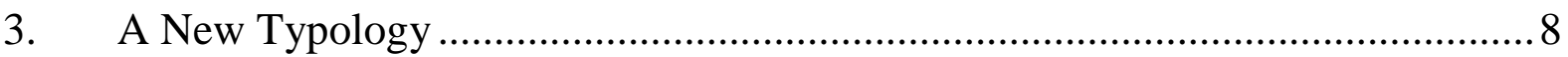

3.1 Participation as Knowledge Transfer (Prescribed-Solidaristic)...................... 10

3.2 Participation as Collective Decision-Making (Negotiated-Solidaristic) .........13

3.3 Participation as Choice and Voice (Negotiated-Agonistic) ........................... 16

3.4 Participation as Arbitration and Oversight (Prescribed-Agonistic)............... 18

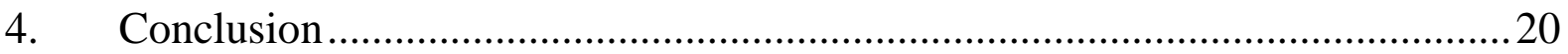

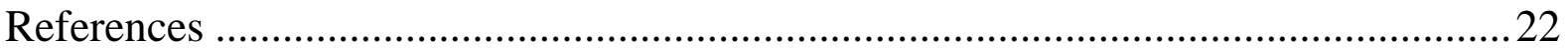

CASE/184

December 2014
Centre for Analysis of Social Exclusion London School of Economics Houghton Street London WC2A $2 \mathrm{AE}$ CASE enquiries - tel: 02079556679 


\section{Centre for Analysis of Social Exclusion}

The Centre for Analysis of Social Exclusion (CASE) is a multi-disciplinary research centre based at the London School of Economics and Political Science (LSE), within the Suntory and Toyota International Centres for Economics and Related Disciplines (STICERD). Our focus is on exploration of different dimensions of social disadvantage, particularly from longitudinal and neighbourhood perspectives, and examination of the impact of public policy.

In addition to our discussion paper series (CASEpapers), we produce occasional summaries of our research in CASEbriefs, and reports from various conferences and activities in CASEreports. All these publications are available to download free from our website. Limited printed copies are available on request.

For further information on the work of the Centre, please contact the Centre Manager, Jane Dickson, on:

Telephone: UK+20 79556679

Fax: $\quad$ UK+207955 6951

Email: $\quad$ j.dickson@1se.ac.uk

Web site: http://sticerd.lse.ac.uk/case

(C) Rikki Dean

All rights reserved. Short sections of text, not to exceed two paragraphs, may be quoted without explicit permission provided that full credit, including (C) notice, is given to the source. 


\title{
Editorial note
}

Rikki Dean is a PhD candidate in the Department of Social Policy at the London School of Economics and CASE.

\begin{abstract}
From the World Bank to the Occupy Movement, support for greater citizen participation in social policy decisions has become ubiquitous. This paper argues that existing typologies of participation are problematic in that they do not recognise the plurality of competing participatory logics that explain this rise in support for participation from groups with such divergent world views. Participatory practice is constructed in multiple ways, and each construction can only be understood with reference to the normative conception of societal organisation it encompasses. However, existing typologies take one of two approaches: either they assume one particular normative bias and categorise participatory forms as accordingly legitimate or illegitimate (for instance, Arnstein's ladder), or they categorise by institutional design features without reference to the broader social and political ideology that informs the use of these designs. This paper draws on Grid-Group Cultural Theory to outline an alternative approach. Participatory practice is categorised along two intersecting dimensions: sociality, the extent to which participation is solidaristic or agonistic, and negotiability, the extent to which participatory spaces are prescribed or negotiated. From these dimensions four archetypes of participation are derived, each with its own participatory logic, conception of the participant, preferred institutional forms, and links to broader social and political philosophies.
\end{abstract}

Key words: public participation; citizen engagement; participatory democracy; deliberative democracy; participatory governance; choice; voice; bureaucracy; health policy; housing policy; social exclusion policy; participation typology; Grid-Group Cultural Theory

Comments to: r.j.dean@1se.ac.uk 


\section{Introduction}

The need for greater public participation in politics and public services has now long been advocated across the political spectrum in Britain. It is an integral component of the current Coalition Government's programme (HM Government 2010), and the Labour opposition's proposition for the next government (Miliband 2014). The idea of the participating citizen is used as a justification for a plethora of policy prescriptions, from marketisation to deliberative governance. This is particularly so in social policy (as opposed to, say, economic or foreign policy), where the practice of participation has become a feature of policy design and service delivery. In healthcare, the NHS now has quite a long history of public and patient involvement from the Community Health Councils established in 1974 through Local Involvement Networks (LINks) to the current body, Healthwatch. Each NHS Trust has a patient and public involvement team, GP practices also host participation forums, and NHS England is currently establishing a national Citizens Assembly. Similarly, in social housing there is history of participation dating back to the 1970s (Hague 1990), and there now exists an extensive architecture for tenant and community participation in housing and regeneration policy. Public participation in social security, poverty and social exclusion policy appears to be a newer phenomenon but is proliferating. Community involvement was embedded into large New Labour projects aimed at tackling social exclusion such as the New Deal for Communities and Sure Start. There was a National Pensions Debate in 2006, the Department for Work and Pensions (DWP) has experimented with deliberative research exercises to inform benefits policies, and there are novel independent initiatives like Glasgow's Poverty Truth Commission, which connects those experiencing poverty with those who make and deliver policy about poverty.

The idea of the participating citizen has also become ubiquitous on a global level; public participation in the policy process is advocated by everyone from the radicals of the Occupy Movement to the econocrats at the World Bank. Moreover, there are multiple influences credited with precipitating this phenomenon. Le Grand (2003) credits the challenge to decision-making by elite bureaucracies to Thatcherism, and the triumph of neo-liberalism over the democratic socialism that animated many of the architects of the welfare state. Whilst neo-liberalism has undoubtedly been an important influence in the rise of the active, participating citizen, Wainright (2003) notes the concurrent influence of the 'participatory left' that grew out of the radical social movements of the Sixties and Seventies, as well as a conservative communitarianism, with its focus on community self-reliance. Others cite what Dryzek (2000) and Elster (1998) have respectively termed the deliberative 'turn' or 'revival' in democratic theory.

The breadth of these advocates for public participation, the precipitating ideological influences, and policy applications, point to the tension behind the apparent consensus in favour of citizen participation. Compare, for instance, the empowered self-interest of the neo-liberal, consumer-citizen with the other-oriented, reasoning-citizen of deliberative democracy and it is clear that, while both philosophies may be animated 
by a notion of the participating citizen, they are different, seemingly incompatible, notions. Participation - like justice, freedom, or fairness - is a polysemous concept that can be constructed in multiple ways, and each construction should be understood with reference to the normative conception of societal organisation it encompasses. However, these competing constructions of participation are rarely given much attention, particularly when it comes to formulating typologies of participatory mechanisms (see, for instance: Arnstein 1969; Pretty 1995; White 1996; Bishop and Davis 2002; Fung 2003; Rowe and Frewer 2005; Smith 2005; Tritter and McCallum 2006; Cornwall 2008). Existing typologies mostly take one of two approaches: either they assume one particular normative bias and categorise participatory forms along a continuum from most to least legitimate, or they categorise by institutional design features without reference to the broader social and political ideology that informs the use of these designs. This article outlines an alternative approach. It attempts to unravel the most common discursive constructions of public participation and how they are situated within broader theories of public administration and social and political theory, as well as demonstrate how these constructions are connected to particular forms of participatory practice.

The aims of this endeavour are twofold. The polysemy of participation is no doubt what makes it beguiling - it enables people with quite different worldviews to coalesce around a common project. However, this can also result in muddled thinking. Although a number of researchers have noted the impact of different ideological influences on the way that participation is both constructed and practised (Pearce 2010; Martin 2008; Parkinson 2004; Papadopoulos and Warin 2007; Abelson et al. 2003; Barnes, Newman, and Sullivan 2007), this has mostly been a tangential component of their studies rather than the direct object of investigation, ${ }^{1}$ thus there is significant scope for further exploration. It is hoped a typology that systematically outlines the different ways we construct participation and the respects in which these constructions are similar and different from each other will help to clarify our understanding and avoid many of the confusions and omissions, detailed throughout this paper, that are characteristic of thinking about public participation in policymaking. In addition, Schmidt's (2008) discursive institutionalism has theorised the power of ideas and discourses in shaping institutional practices. A muddled participatory ideology is likely to lead to muddled institutional practices. A greater understanding of the different ways that public participation is constructed could help to improve the practice of participation, for instance; this paper highlights how some of the tensions that surround actual instances of public participation may be attributed to unacknowledged differences in the way participation is constructed by different actors in the process. Greater clarity about the ways participation can be constructed may therefore help to reduce conflict in the practice of participation. 


\section{Existing Typologies of Participation}

First published more than forty years ago, Arnstein's (1969) ladder of citizen participation has been influential in shaping the way academics and policy-makers think about participation (Tritter and McCallum 2006; Cornwall 2008). Its legacy is apparent in the number of typologies of citizen participation that arrange types of participation in a hierarchy from worst to best, a technique Bishop and Davis (2002) have coined the 'continuum model'. Arnstein views participation with an activist's eye, as an insurgency against government power: "citizen participation is a categorical term for citizen power. It is the redistribution of power..." (1969: 216). Accordingly, she arranges types of participation on an eight-rung ladder based on the extent to which it enables citizens to exercise power. In order from bottom to top, the first two rungs - manipulation and therapy - are classified as degrees of non-participation, the next three rungs - informing, consultation and placation - are degrees of tokenism, and the top three rungs - partnership, delegated power and citizen control - are termed degrees of citizen power (Ibid: 217). Arnstein's article is overtly normative throughout, and this is apparent in her typology; the terms non-participation and tokenism, used to classify the different participation types, have obvious connotations of illegitimacy. It is clear that only the top three rungs of the ladder are considered appropriate forms of participation and of these, citizen control is the apogee.

This normative bias is a common feature of continuum models for classifying participatory mechanisms, for instance; Pretty's (1995) typology moves through several stages from manipulative participation to interactive participation and selfmobilization, whilst White's (1996) categories range from nominal to transformative. However, as Bishop and Davis (2002) have noted, the use of strongly normative typologies of participation is inherently problematic when participation is subject to competing definitions. It is unlikely that a typology that is normatively skewed towards one construction of participation can do justice to the variety of alternative constructions. While it may be tempting to dismiss all those forms of participation that do not fit with one's own preferred construction, this limits the use of the typology and also restricts our understanding of different forms of participation; it makes no genuine attempt to discover why these other forms of participation are legitimate within the theoretical framework in which their advocates operate; it only denigrates them and, as such, is unlikely to meet with widespread acceptance in more than a superficial sense. The lack of recognition of the normative assumptions that underpin one's construction of participation and their influence is often played out in debates in this literature, for instance; in an extensive critique of Arnstein's ladder, Tritter and McCallum argue, "it conflates means and ends, implying that user empowerment should be the sole aim" (2006: 162). The substitution of the term user empowerment for citizen control itself hints that Tritter and McCallum are operating with an alternative conception of participation. More importantly, Arnstein would likely reject their claim outright. For Arnstein, citizen control is an end-in-itself and this is integral to her conception of participation; Tritter and McCallum's rejection of this simply demonstrates they are working with a more instrumental conception than Arnstein. It is thus questionable whether such debates are reconcilable given that they are 
predicated on incommensurable ideas of participation, which emphasises not only the importance of recognising the plurality of constructions of participation but also that a typology of participation needs to be compatible with multiple alternative constructions.

An alternative, less overtly normative, method for classifying participatory mechanisms is to generate a typology based on a range of institutional design features. Fung (2003) and Rowe and Frewer (2005) adopt such an approach. Rowe and Frewer (2005) first identify three classes of what they call engagement (rather than participation) based on the direction of flow of information between public and the sponsor of the engagement process. Processes with unidirectional flow of information from sponsor to public are termed communication, unidirectional flow of information from public to sponsor is called consultation, and a bidirectional exchange is called participation. These three classes of engagement mechanisms are then further divided based on six salient features of their institutional design, such as the participant selection method, into fourteen categories (four communication types, six consultation types, and four participation types). Rather than trying to provide a comprehensive categorisation of different types of participation, Fung (Fung 2003) maps a selection of actual participatory initiatives onto a range of design features to demonstrate how these features impact on the realisation of many of the touted benefits of participation. Accordingly, this classification is only loosely speaking a typology, although, in principle, it would be possible to apply these features more generally in order to produce an alternative version of Rowe and Frewer's (2005) typology.

When opposed to the continuum model typologies, the typologies by institutional design features are comparatively normatively neutral. This decoupling from a normative basis for participation is a potential benefit in that it is not prescriptive about types of participation and thus is potentially more widely acceptable. However, it does reduce the amount of information provided by the typology. The continuum model implicitly provides us with a description of which institutional forms are compatible with which normative biases, whereas there is no comparable information within the typologies by institutional design features, as they are somewhat disconnected from the wider debates regarding what constitutes legitimate participation. Rowe and Frewer (2005) and Fung (2003) provide us with information regarding which institutional forms will realise which goals, but, as they themselves note, there is no way to judge which goals might be desirable without reconnecting to these debates and picking a normative position. On this dimension the continuum model is richer, but it only provides a partial account, since we only discover those participation types that are respectively favoured and rejected within the one bias. Moreover it fails to highlight how an institutional design may be altered by the way it is discursively constructed; for instance, Sintomer, Herzberg and Roecke (2008) have outlined the variety of approaches to participatory budgeting as it has been transferred from its Brazilian origins into different European contexts. The ideal typology would capture the strengths of both approaches by providing a typology of modes of participation, that connect particular institutional practices to the broader construction of participation from which they draw their meaning. 
Bishop and Davis (2002) go some way towards a typology of modes of participation. Based on the argument that "There is no single methodology for policy participation, and no shared theoretical base" (Ibid: 21), they argue, contra the continuum model, for a discontinuous typology and identify five types - consultation, partnership, standing, consumer choice, and control - each of which "has a public rationale, and a characteristic set of policy instruments. (Ibid: 26). However, this typology also has its weaknesses. It is explicitly ad hoc, "Given frequent innovation in participation processes, any classification must be provisional" (Ibid: 26). Ad hoc identification of types raises a number a questions as to the extent the types are discreet, mutually exclusive, jointly exhaustive and of a similar kind. There are some reasons to doubt whether Bishop and Davis' (2002) typology meets these conditions, for instance; they point to the use of one of their categories (consultation) within another category (consumer choice), suggesting that the categories may not be mutually exclusive or of the same kind. There are also no dimensions on which their ad hoc types are ordered, meaning it is difficult to understand how the different types relate to one another.

The next section of the article attempts to address the four issues identified above by outlining a typology that: 1) explores the plurality of constructions of public participation in the policy-process; 2) does not categorise participation mechanisms according to one normative bias; 3 ) attempts to connect particular institutional forms of participation to the broader constructions of participation; 4) orders types of participation along persisting theoretical dimensions, rather than identifying types through ad hoc observation.

\section{A New Typology}

The typology proposed in this article posits four archetypes of public participation, organised on two, intersecting dimensions: sociality and negotiability. These dimensions resonate with the Grid-Group Cultural Theory, originally proposed by anthropologist Mary Douglas (1970) in order to categorise traditional societies, and which has since been employed in a wide variety of fields. This article draws inspiration from two more recent manifestations of similar typologies, namely; Christopher Hood's (1998) classification of modes of public administration and Hartley Dean's (2013) taxonomy of modes of social citizenship.

The horizontal, sociality dimension of the typology concerns the extent to which the participatory space is agonistic or solidaristic. An agonistic participatory is conflictual with individuals and groups predominantly concerned with promoting and defending their own interests and values against other participants. In a solidaristic participatory space, on the contrary, participants view themselves as interdependent members of a social collective and participation is oriented towards collective ends and the common good. Whether humans are predominantly cooperative or competitive, and thus whether social relations should be agonistic or solidaristic has been a point of contestation in political and social theory for hundreds of years - it divides Rousseau from Hobbes and more latterly Foucault from Habermas. It has been an important 
component of deliberative democrats' critique of aggregative, liberal democracy (Dryzek 2000). Moreover, it has been a central concern in recent programmes for reform of public services and public administration (Le Grand 2003). In Beyond Adversary Democracy Mansbridge (1980) used a similar dimension to distinguish between adversary and unitary democracy, noting some of the implications for the practice of citizen participation, and there is increasing interest, following Mouffe (2000), in agonistic conceptions of democracy. Despite this, the literature that focuses more specifically on the institutional practices of public participation, tends towards a presumption in favour of solidaristic forms and neglects their agonistic counterpart. This is perhaps why market-based mechanisms for empowering the public are rarely considered forms of public participation despite the critical importance of the participation of citizen-consumers for this theory of public administration. Accordingly, the typology elaborated in this article should help to remedy this neglect of agonistic forms of participation.

The vertical, negotiability dimension concerns the extent to which the participatory space is prescribed or negotiated. In prescribed participatory spaces questions such as who participates, and about what, are determined outside of the space (perhaps by the commissioning organisation, perhaps by circumstance) and imposed upon the participants, who thus have little scope to determine the conditions of their participation. In negotiated participatory spaces the obverse obtains, participants are able to negotiate who participates, the intended ends of their participation, and the rules of interaction between participants. Once again, a similar theme has been at the heart of long-standing debates about democracy, for instance; the tension between popular sovereignty and liberal rights, and their relative primacy, which has been the distinguishing feature of arguments between republicans and liberals. Whether public organisations should be constrained by overt rules, standards or targets imposed from above, or free to manage by discretion has also been a long-standing feature of prescriptions for good public management (Baldwin 1997; Hood 1998) and was a central debate in New Labour's approach to public administration (Barber 2007; Le Grand 2008). In addition, the extent to which participants can negotiate the conditions of the participatory space, though not synonymous with 'citizen power', resonates with the dimension that underpins Arnstein's ladder and the implicit dimension that underpins the now more commonly employed IAP2 public participation spectrum.

Now it has been established that the two dimensions that underpin the new typology are a salient feature of debates about the appropriate institutional forms of public participation, as well as long-standing points of contention in democratic theory and public administration theory, which are both likely to influence the ways in which participation is more broadly constructed, the article will next consider each of the four types that constitute the typology. It must be remembered that this typology is intended to be a useful heuristic that captures the main differences between alternative modes of participation. Nevertheless, the real world is of course messier than the neat conceptual classifications set-out below. Each of the four types refers only to the ways that public participation is incorporated into policy-level decision-making processes. Unfortunately, it is beyond the scope of this article to address other forms of 
participation, such as co-production, whereby the public and state jointly deliver services, however; this is not to impugn those types of participation as lesser forms, and it may be possible to extend the typology to include them in the future.

Figure 1: A Typology of Modes of Public Participation

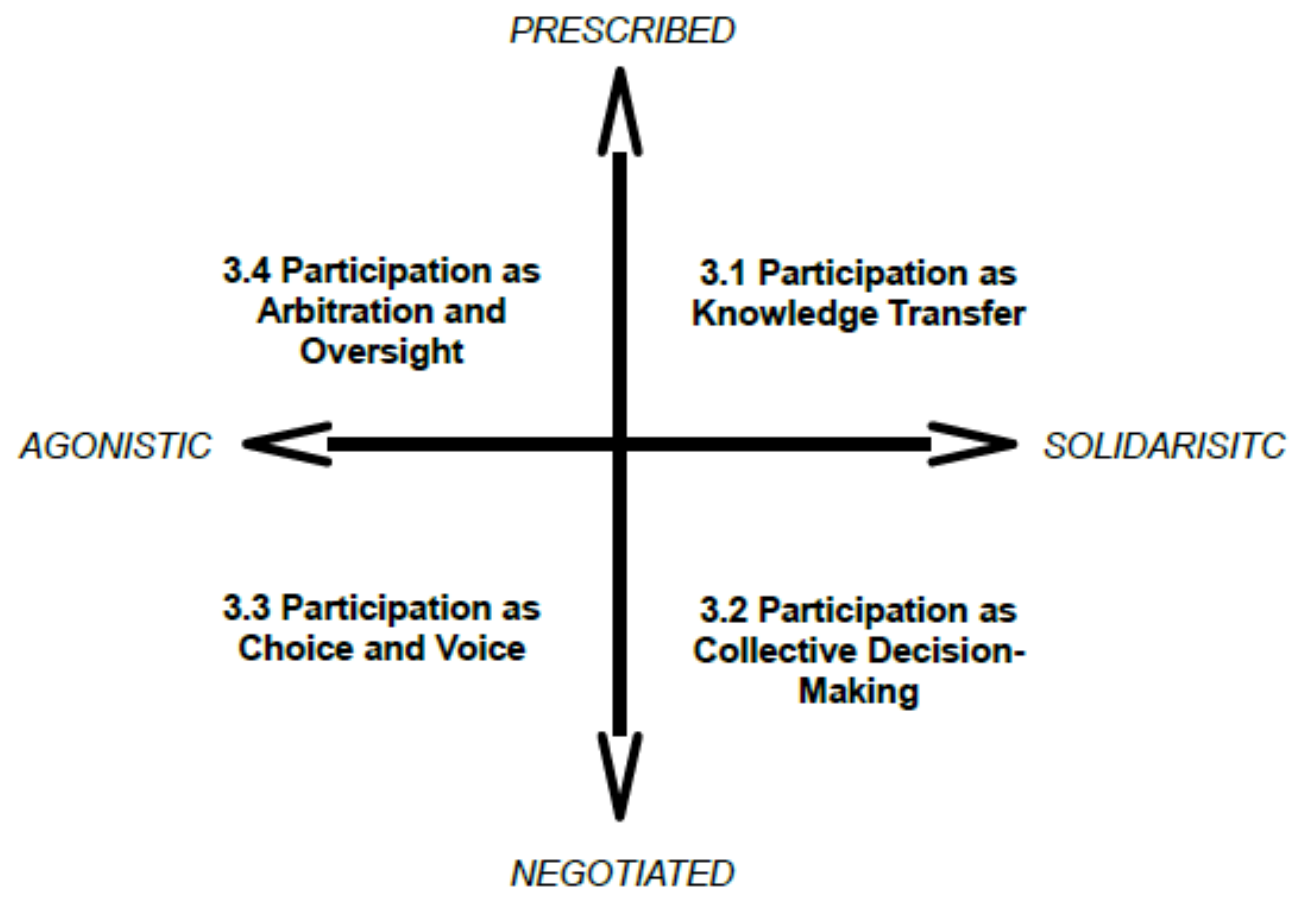

\subsection{Participation as Knowledge Transfer (Prescribed-Solidaristic)}

This exploration of the four modes of participatory decision-processes begins with forms of participation that are prescribed and solidaristic. The participants have little control over the participatory space but they view themselves and the other participants as interdependent fellows of a unified community with common goals and interests. This resonates with what Hood (1998) terms the 'hierarchist way' of doing public management in his grid-group typology of approaches to public administration. Hierarchical forms of organisation may seem a strange place to begin an exegesis of public participation, given the two are more commonly thought to be in opposition. Public participation is often posited as an alternative to bureaucratic hierarchies (Fung 2004; Le Grand 2008), and one of the foremost proponents of hierarchical government, Plato, saw democracy as one step from tyranny, an orgy of instant gratification at the expense of wisdom and self-discipline. However, careful examination of the tenets of hierarchical organisation demonstrates how it can, and often does, profitably accommodate public participation.

In The Republic Plato documents a discussion between Socrates and some of his followers regarding the founding of an ideal city that encompasses many of the traits common to hierarchical forms of government. The city is divided in three strata: the guardians, the auxiliaries, and the commercial class. This stratification of society is 
based on the common justification for hierarchical social relations, namely, it is in the interests of society as a whole for each individual to carry out the function for which he or she is most suited.

"What is our aim in appointing these guardians? Is it to provide the greatest possible happiness for them? Or does our aim concern the whole city? Aren't we seeing if we can provide the greatest degree of happiness for that? Isn't that what we should be compelling these auxiliaries and guardians to do? Shouldn't we be persuading them - and everyone else likewise - to be the best possible practitioners of their own particular task? And when as a result the city prospers and is well established, can't we then leave it to each group's own nature to give it a share of happiness." (421c)

It is the guardians who are to rule the city and have responsibility for its social administration, including the education of the populace and the prevention of poverty and wealth. Their name gives an indication of the type of ruler they are expected to be - "wise, powerful and above all devoted to the city" (Ibid, 412c) - they are custodians of the collective interest, who should forgo the pleasures of ordinary citizens and conduct themselves to be beyond suspicion. The guardians' claims to exert authority are based in their superior wisdom, primarily construed as reason and rational calculation. To ensure only the most wise and incorruptible obtain the position of guardian, the position is open to individuals of all classes and each guardian is appointed on merit, after extensive testing of their fitness to rule.

For Weber, often considered the foremost theorist of bureaucracy (Albrow 1970), bureacractic claims to authority are also based on knowledge, though now construed as specialist expertise and rationality. There are important distinctions between the Platonic ideal city and Weberian bureaucracy - in Weberian bureaucracy public and private life is decoupled, so authority resides in a depersonalised system of official duties and general rules, rather than with enlightened individuals - however, much of the Platonic conception remains. As well as the focus on rationality as a basis for authority, this includes: the division of society into three strata of governors, their functionaries, and the governed (Albrow 1970) the idea that bureaucracy is beneficial for all the population, due to its technical efficiency; meritocratic appointment of official positions after extensive training and examination; and the prescription that officials should not use office for the pursuit of their own self-interest or their own personal policy preferences (Weber 1922: 956-988).

Weber's orientation to democracy is a further important development on the Platonic conception. Weber is wary of the totalising power of administrative bureaucracy and looks towards democracy as a locus of control. ${ }^{2}$ However, he is pessimistic about the potential for democracy to realise popular control. The complexity of modern societies

2

This is a theme that is pursued more recently, and in extensive detail, by Habermas (1996), both in respect to the colonisation of the lifeworld by system, and the relation between administrative and communicative power. 
renders direct democracy infeasible. This complexity also means that political judgement is itself a form of technical expertise that cannot be accessed by the laity and must be honed by specialists. Judgements based on public opinion can never be more than demagogic, and political leadership is indispensable (Shaw 2008). ${ }^{3}$ Though they are more optimistic about the role of public opinion and the extent to which representative democracy equates to popular control, Sydney and Beatrice Webb subscribe to a similar position in their prescriptions for the social administration of Britain. Like Weber, they separate bureaucratic administration from political control, and point to the role of political leaders in ascertaining and formulating the "Common Will" (Webb and Webb 1920). We emerge with a political-administrative model of policy-making in which it is the role of political leaders to use expert political judgement to ascertain and formulate the general interest of the population and direct the administration towards providing for this general interest. The role of the administration is to bring to bear the requisite specialist expertise and rational judgement to efficiently provide for this general interest.

This model of policy-making entails two rationales for public participation in the process, both of which are constructed as knowledge transfer opportunities. The first rationale is that in order to correctly interpret the 'common will' of the population, political leaders will need good information about that population, their needs and values. Accordingly, they may invite the public to participate in processes that capture those needs and values, so we see participation justified on the basis that, "Understanding peoples' needs, preferences and values by talking with them is a way to enhance the effectiveness of decision-making and service provision" (Involve 2005: 22). The participatory principle is based on pragmatism; participation is to improve outcomes, not because of a right to participate.

The second rationale is also concerned with improving outcomes. The public is invited to participate where it is seen to possess expertise that can improve the effectiveness of a policy decision, participation "allows government to tap wider sources of information, perspectives and potential solutions, and improves the quality of decisions reached" (Cabinet Office 2002: 5). This also helps to remedy an inherent weakness of stratified political systems in modern societies; the lives of elite decisionmakers rarely follow the patterns of those of the 'common man', and so the public is particularly valued for its experiential knowledge of situations that elites rarely encounter, such as poverty. Weber may have based the technical superiority of bureaucracy on the increasing complexity of modern societies, but advocates of participation frequently cite the increasing heterogeneity of society, and a supposedly more educated and less deferential population, as reasons why bureaucratic elites cannot claim a monopoly on expertise (Involve 2005; HM Government 2012)

Unlike the monopoly on specialist expertise, the monopoly on rational judgement remains with political and bureaucratic elites within this model. It is important to we will later return. 
stress that these processes are not commissioned in order that the public can directly instruct policy-makers what to do. The public participants are viewed as information units, providing inputs into a process of expert interpretation and decision-making,

"Public involvement contributes to evidence based policy-making. But it is only one source of evidence. The advice and decisions of policy makers will involve balancing evidence from a wide range of sources, including existing and new research; economic modelling; regulatory impact assessments; evaluation and scientific, technical and expert advice." (Cabinet Office 2002: 5).

The construction of participation as an opportunity for the public to transfer knowledge to public-spirited, expert decision-makers is likely to be accompanied by particular institutional practices of participation. Processes are likely to be stratified, with specialist roles reserved for expert decision-makers and facilitators which delineate them from ordinary participants. Still, those involved in the process will be encouraged to see each other as partners, who are all making their own valuable contribution towards a common goal, usually an improved policy outcome, thus bargaining or strategic game playing by participants will be discouraged. In addition, the participatory space is likely to be an invited space in which the public is invited to contribute towards an agenda that is pre-determined by an organisation's policy priorities. Similarly, who is to participate will be decided according to this predetermined agenda, with the public organisation retaining control over both which participant selection method to use, and then who should be selected. Nonetheless, given that the efficacy of a participation process within this participatory mode is chiefly based on its contribution to improved policy outcomes, the focus is not so much on one particular participatory form, but that the form should be tailored to best attain the desired outcomes.

\subsection{Participation as Collective Decision-Making (Negotiated-Solidaristic)}

Our second mode of participation is that primarily associated with the participatory left. It rejects the role differentiation, particularly the distinction between governed and governors, that characterised the previous mode in favour of a vision of selfgovernment through collective decision-making, "participation refers to (equal) participation in the making of decisions and 'political equality' refers to equality of power in determining the outcome of decisions" (Pateman 1970: 43). The express notion of participatory democracy advocated by Pateman may have originated in the US, out of the social movements of the 1960s and 1970s, but it has long roots that have found expression in diverse forms throughout history - from Ancient Athenian democracy and the political thought of Rousseau to the anarchism of Bakhunin and the Rochdale Principles of the English Cooperative Movement. Nonetheless, Pateman (1970) is a useful starting point as, drawing on Rousseau, JS Mill and GDH Cole, her theory of participatory democracy weaves together five of the essential principles that have characterised this mode of participation.

The first principle is the direct participation of all in the taking of decisions, based on Rousseau's notion of liberty, that we are free in as far as we are the co-authors of the 
decisions to which we are subject. The second, a general condition of political equality, is a corollary of the first - we can only be said to be co-authors of decisions if we have equal power to determine them, thus no person should be able to dominate another. Therefore, we are presented with a theory of democratic self-government in which a society of interdependent equals collectively (usually consensually) take decisions to which they are all equally subject. Third is the principle of subsidiarity, that decision-making should take place at the lowest appropriate (usually geographically defined) level and cascade up. The fourth principle is that participation should not be limited to the political. Participatory democracy entails a participatory society in which participation in political, social, civic, and economic decision-making is woven into the fabric of a citizen's everyday life. The final, fifth principle is that participation is, in the broadest sense, educational. It is essential to both the socialisation of citizens and the full realisation of human capacities, as such, it resonates with Hartley Dean's (2013) eudaimonic conception of human needs.

A brief consideration of the position of deliberative democracy within this typology is also necessary, given its influence has arguably superseded participatory democracy, at least in the Academy. Deliberative democracy appears to be overtly solidaristic in nature, given its rejection of deliberation as strategic bargaining between actors with pre-political interests in favour of a conception that emphasises the reflective transformation of preferences, consensus and the common good (Dryzek 2000). It is, however, less clear where deliberative democracy stands on the negotiability dimension. Though there seems to be a general presumption that participation should be negotiated, deliberative democrats may show greater commitment to the quality of opinion formation than to the idea of direct participation if the two come into conflict (Papadopoulos and Warin 2007). Habermas (1996), for instance, moves away from the idea that democratic decisions should be taken by all those affected, or even involve the deliberation of all those affected, towards the idea that a decision is legitimate if all those affected could assent as participants in rational discourse. Therefore, it is perhaps possible for more prescribed forms of participation to be compatible with deliberative democracy, if they contribute to a decision's rational acceptability, or feed into broader public discussion.

Although, as aforementioned, the return to fashion of participatory democracy in the 1990s and the ascendency of deliberative democracy are often credited with driving the upsurge in participatory policy-making initiatives, it is quite rare to see their radical egalitarian forms given serious consideration as a practicable component of a theory of public administration. One might expect to find some synergy with theories of network governance, which incorporates similar principles of interdependence, autonomy, negotiation and trust (Sørensen and Torfing 2005). However, those theorists of network governance that have considered the role of public participation (Sørensen and Torfing 2005; Bingham, Nabatchi, and O'Leary 2005) give little attention to the direct forms of popular control that sit at the top of Arnstein's ladder and are envisaged by participatory democrats like Pateman. Moreover, Dryzek (2010), though optimistic regarding the potential of a 'deliberative governance', doubts the possibilities for popular control of governance networks given the difficulty of even 
conceptualising an appropriate public to which a network corresponds. Baccaro and Papadakis (2009) are also sceptical of the possibilities for a 'participatory-deliberative public administration' and favour the Habermasian 'two-track' model in which public participation takes place in a free-wheeling public sphere that influences but is separate to institutionalised processes of official decision-making.

This lack of fit with theories of public administration is mirrored in the lack of practise of these radical egalitarian modes of public participation in official spheres of policy decision-making, at least in the UK. Although the rhetoric of participatory democracy has become prevalent - for instance, all three major political parties advocate giving power to real/ordinary/local people in recent manifestos - the practice of popular control through consensual decision processes is rare even at local level. Accordingly, Barnes, Newman and Sullivan (2007) locate pressure for inclusive democracy outside the state and in contradistinction to four 'official' discourses of participation, and previous work by this author (2012) has shown that official evaluations of deliberative participation initiatives pay scant regard to principles of deliberative democracy. Even in the field of international development, which is often thought to be heavily influenced by participatory democratic thinking (Hood 1998), the participatory initiatives undertaken by organisations such as the World Bank and UNDP tend to be participatory research exercises rather than participatory decisionmaking (see, for instance, (Kim 2013)). Perhaps the most impressive official formalisation of participatory democratic principles is in Venezuela's extensive network of communal councils, which were seen by President Chavez as an antisystemic force to transcend the bourgeois state and create a communal state (Azzellini 2013). Nonetheless, in the UK, this mode of participation mostly remains a hypothetical possibility for making policy decisions.

There are however examples in the UK where participatory democratic prescriptions for decision processes are realised in social movements and civil society. The aforementioned Glasgow Poverty Truth Commission creates an egalitarian space where those who experience poverty can collaborate on first name terms with public officials, relying on the power of the resultant personal relationships to drive policy change. Occupy London also appeared to be heavily influenced by participatory democracy and examining its professed decision procedures can illuminate the institutional practices typical of this mode of participation. ${ }^{4}$ Like the knowledge transfer mode of participation these processes are solidaristic - interactions between participants are characterised by mutual respect, strategic behaviour based on securing personal preferences is discouraged in favour of public reason-giving, and the resolution of any conflicts proceeds through discussion oriented towards mutual understanding. Unlike the hierarchical mode, the purposes and nature of the initiative are negotiated between the participants, rather than prescribed from outside the participatory space. The agenda is not pre-set, but collectively set by the participants

4 The following is based on information on the Occupy London website: http://occupylondon.org.uk/10811-2/; http://occupylondon.org.uk/how-a-general-assemblyworks/; and http://occupylondon.org.uk/about/statements/safer-space-policy/ (All accessed 21/11/2013). 
and anyone can contribute a topic for discussion. Participation is open to anyone, rather than participants being selected, and restrictions on participation in order to achieve representativeness or some other criteria would likely be rejected. The rules of appropriate behaviour and the ways in which the business of the participatory space is to be conducted are also collectively determined by the participants, and always open to re-negotiation. As Polletta (2014) notes, though radical egalitarian organisation is often seen as leaderless, a better description is that everyone is seen as a potential leader, so whilst there is no overall leader of the entire process, leadership responsibility for particular tasks is continually negotiated between participants. Nonetheless, there is no special elite group of 'decision-makers', and decisions are prosecuted through collective discussion in which each participant can wield an effective veto, thus the aim is to reach group consensus.

\subsection{Participation as Choice and Voice (Negotiated-Agonistic)}

Our third mode of participation, the first of our agonistic types, has an equal disregard for the authority of elites, but would reject the radical egalitarian preoccupation with a collective search for the common good. It is characterised by a utilitarian methodological individualism that holds the general interest is no more or less than the sum total of all the individual interests of persons composing the group (see for instance, (Bentham 1789). The enduring popularity of this utilitarian thinking is demonstrated in the recent moves by both France and the UK to measure the effectiveness of government according to gross national happiness; viz., by totting up the individual happiness of each citizen into an overall measure, a practice which Bentham advocated in the $1780 \mathrm{~s}$. This mode is also informed by the idea of Homo economicus: individuals have pre-political interests and values which they are driven to try to protect or secure; they are, on the whole, the best judge of those interests; and, they will respond to incentives based on those interests. These ideas can be traced back to at least Adam Smith and his oft-cited quote from the Wealth of Nations that to secure our dinner we should address ourselves to the self-love of the butcher and baker, not their humanity (1776: 119). In addition, there is a presumption that the process of each individual pursuing their own interests results in a self-regulating system of spontaneous order that produces social benefits (even Pareto Optimality). Again, this is often attributed to Adam Smith and the metaphor of the invisible hand, though with some controversy, however; it is explicit in the work of Hayek,

"It is, indeed, part of the liberal attitude to assume that, especially in the economic field, the self-regulating forces of the market will somehow bring about the required adjustments to new conditions, although no-one can foretell how they will do this in a particular instance" (Hayek 1960: 346).

These ideas may more commonly be associated with the field of economics, but as Hayek notes, they are also a central component of political liberalism and cognate doctrines, and in this section I will outline how they have been constituted as a theory of democracy, a theory of public administration, and how they should be considered as a mode of public participation in policy-making, given the not inconsiderable irony that they are inherently sceptical of what is usually thought of as the policy process. 
Schumpeter's influential Capitalism, Socialism and Democracy is often credited with precipitating the conception of democracy as competition (e.g. Mouffe 2000), but Schumpeter's model is overtly elitist in a way that political liberalism would usually reject. A more purely individualistic conception is expressed in Downs' Economic Theory of Democracy, which sets out a model in which "parties in democratic politics are analogous to entrepreneurs in a profit-seeking economy" (1957: 295). Political actors - politicians, parties, governments - are vote-maximisers. They are in possession of their own goals but the realisation of these goals is predicated on political support. Accordingly, political actors are engaged in a continuous competitive struggle with one another to maximise political support, and any decision will be calculated with that end in mind. The voters that they compete for are themselves utility maximisers. They decide on who to vote for by calculating the expected utility income from each of their potential political choices and selecting the one that provides the greatest return (so long as that alternative has a realistic chance of being elected). It is a model of democracy that gives considerable power to individual voters since political actors are beholden to their preferences. It has often been termed aggregative democracy by its critics (Mouffe 2000; Dryzek 2000) as political decisions are calculated by summing the individual preferences of voters.

Public servants appear to have retained their air of public-spirited altruism longer than the politicians, but not much longer - since the 1970s the 'knightly' motivations of public servants have been viewed with increasing scepticism (Le Grand 2003). As a result, the market-based approach to public administration is increasingly popular. It is a central ingredient of the recipes for entrepreneurial public sector reform espoused by Osborne and Gaebler (1993), who attained guru status with the Clinton administration (Hood 1998), but the most sophisticated exponent of this general approach is arguably Le Grand (2003; 2008), who helped drive New Labour's market-based reforms of the NHS. Though it is not possible to do justice to the various nuances of Le Grand's position here, its kernel is that competition between service providers (e.g. hospitals and schools) for the custom of service users (patients and parents), who have the power to choose their provider, will result in greater quality, efficiency and responsiveness of services and greater equity and autonomy for the users of those services, through the other invisible hand of state facilitated quasi-markets.

The primary political/social act according to the economic theory of democracy and the market approach to public administration is thus for individual citizens to express their preferences through choice, whether it is by casting a vote or choosing a service provider. It may be objected that this article set out to uncover the variety of different ways the public participates in policy-level decisions, and choosing one's healthcare provider is not participation in a policy-level decision. However, consider the decision process involved in closing a failing school or hospital. Within the knowledge transfer mode, this decision would be made by expert policy elites with appropriate input from the public, perhaps a consultation. Within the collective decision-making mode, the decision would be made through collective discussion and unanimity decision amongst all those affected. Le Grand (2008), however, proposes that these decisions should be de-politicised, enforced by an independent agency that decides by applying 
specified rules regarding market performance. The individual decisions of citizens in the market thus become a de facto process of policy-level decision-making, therefore choice should be regarded as a form of public participation in policy-making. Moreover, it is absolutely essential to the functioning of the market system - if citizens refuse to make choices based on expected utility incomes then the benefits of the market are never realised - as such, public participation as choice is a doctrinal component of market-based approaches to social policy.

There are a range of secondary mechanisms of participation that are also commonplace within this mode of participation, for instance; complaints procedures, customer satisfaction surveys, and interest group lobbying. As Le Grand (2008) notes, if service providers are trying to attract your custom they have a strong incentive to listen if you choose to voice your wants and needs (as do political parties trying to attract your vote). Therefore, politicians and public service organisations are likely to set up processes that allow you to express your preferences to them because your preferences are a direct form of market intelligence. Preferences expressed through interest group lobbying should also find a sympathetic ear if meeting them can increase the 'market share' of politicians and public service organisations.

The construction of participation as choice and voice differs from the two previous modes of participation outlined in this paper since it is the first in which participation is oriented towards expressing individual preferences rather than an attempt to reach a form of mutual understanding or address the common good. Again this construction is coupled with particular forms of institutional practice. Participation mechanisms will tend to facilitate interactions between individual citizens and politicians or public organisations rather than between citizens. The goal of participation is responsiveness: politicians and public organisations should listen to citizens' preferences and do what they say (unless there is a larger group of citizens who express opposing preferences), which is quite different from the knowledge transfer mode, where public participation is just one of a number of inputs that need to be weighed in the decision process. Nonetheless, public voices do not have a decision-making role, such as that in the collective decision-making mode. This is unnecessary since they can exercise their power through making choices in the marketplace. What is similar to the collective decision-making mode is the scope of the public to determine their own agenda for participation. Individual citizens and interest groups decide what preferences they want to express so set the terms of the debate, and they do so in a manner and at a time of their choosing.

\subsection{Participation as Arbitration and Oversight (Prescribed-Agonistic)}

Our fourth and final mode of participation is also based on an agonistic construction of society in which there is continual conflict between individuals and groups to realise their own interests, preferences and values. However, this mode is sceptical of the proposition, characteristic of the previous mode, that all this competition leads to spontaneous order and social benefits. For Hobbes, a society left unregulated by a common power will degenerate into civil war as men "make warre upon each other, for their particular interests" (1651: 225). Unlike the bees and ants, humans cannot be 
trusted to live peaceably together without compulsion; individuals will renege on agreements with each other when it is in their interests to do so, thus no one's word can be trusted and coordinated action becomes impossible. Therefore, to avoid the chaos of war, each individual agrees to give power to a common sovereign. The role of the sovereign is to keep the peace, primarily by protecting citizens from each other by enforcing the rules of the game (the keeping of covenants) and adjudicating between competing interests. Although pluralism is often seen as the antithesis of Hobbes' call for absolute monarchy, similar ideas can be found in at least one strand of pluralism according to Dunleavy and O'Leary (1987). They argue that much pluralist thinking adopts a notion of the neutral state in which the state acts as referee between interest groups, working to uphold customary norms and intervening to punish transgressors.

The notion of the neutral state, like the state's claim to a monopoly on expertise, has been attacked by a number of quite different theoretical traditions: Marxists have claimed the state in capitalist society is an instrument of bourgeois power; the New Right has claimed that state actors follow their own private interests (as discussed above); and, even within pluralism, there are competing notions of the state, for instance, as simply a mirror of the balance of interests (Dunleavy and O'Leary 1987). Just as the challenge to the state's monopoly on expertise opened up a potential sphere for public participation, so does the challenge to the state's neutrality. If the state cannot be trusted to play the role of impartial adjudicator, perhaps the public can. Alternatively, processes of contrived randomness have a long history as techniques for public administration where there are concerns about interest group capture of the state; in classical Athens public auditors were selected by lot, and Burnheim's demarchy also advocates the oversight of government bureaucracies by committees of citizens selected by lot (Hood 1998). This provides two potential rationales for public participation: first, to substitute for the state as impartial adjudicator (arbitration) or, second, to play impartial critic of state activity (oversight). In both cases the objective of participation is to improve the legitimacy of decisions and render them acceptable to all, primarily by demonstrating that decisions have been subject to a fair process that has not been dominated by of one set of vested interests.

This construction of public participation is rarely given much attention in the literature on public participation in policy-making, but the most widespread example of citizen participation in the business of the state is in exactly this kind of role - as randomly selected members of a jury in a legal trial. Though trial juries are not a form of policy decision-making, they were an inspiration for the policy innovation of citizens' juries that have increasingly been employed as a public participation mechanism in recent years. Moreover, Parkinson (2004) has argued that citizens' juries have been employed in this fashion, as a means to break through deadlocks in public debates that have become a polarised battle between interest groups. Bingham, Nabatchi and O'Leary (2005) have also noted the tendency for the public to take on a quasi-judicial role in new governance processes such as mediation, facilitation, minitrials and arbitration. Though it is rarely overtly stated as an aim of participation in the grey literature, the implicit logic of this construction of participation does seem to pervade 
quite widely, in particular the focus on excluding 'vested interests' from the process to ensure decision legitimacy is a common theme. ${ }^{5}$ It is usually perceived as an attempt by public organisations to control the process by excluding more informed and articulate participants, but the quest for impartiality may provide a legitimate rationale for excluding certain groups.

The importance of neutrality in this construction points to some key features of likely institutional practices within this mode of participation. Selection of participants will be tightly controlled. Who participates is of crucial importance to the legitimacy of the process and the acceptability of any decisions it reaches, so there will be clear criteria for demonstrating that the selection of participants has not prejudiced the final outcome. Therefore, participants will be selected at random or selected for their impartiality, namely; their lack of any links to the interest groups with a stake in the outcome of the process. If the mechanism is an ongoing process there are also likely to be limited terms for participants, since this reduces incentives for interest groups to try to co-opt participants to their cause. A specific agenda that participants are entrusted with prosecuting will also be determined in advance - this is a necessary pre-requisite for selecting impartial participants and also prevents participants adapting the process to pursue their own interests. Participation is likely to be adversarial. Those with an interest in the decision present their case to the impartial adjudicators, who are expected to interrogate their arguments and come to a balanced decision. Finally, the output of the process will carry considerable weight - it may be a decision that all parties are expected to abide by, or a report to which a public organisation is compelled to respond.

\section{Conclusion}

This article has attempted to present a typology of participation that goes beyond the radicalism and resignation of the most common approach to classifying participation mechanisms, which situates radical democracy as the apogee of participatory practice and any deviation from its principles as the "appropriation by mainstream institutions of discourses and concepts (among them participation) expressing emancipatory hopes and turning them into new tyrannies" (Pearce 2010: 15). It has shown that public participation is not necessarily in opposition to hierarchy and institutional power, it has a legitimate complementary role in such systems, and this is often how it is constructed by public organisations. That is not to say we should refrain from arguments about what the right forms of participation are, only that these arguments should be directed towards contesting the actual assumptions of alternative constructions, rather than simply presuming others are bastardising the ideas of participatory democracy.

5

See, for instance, the recent Public Administration Select Committee report (2013), Public Engagement in Policy-Making. 
Participatory democracy has no monopoly on claims to public participation. There are a range of competing normative constructions of participation linked to a range of competing normative constructions of government and public administration. Given these constructions date back hundreds of years, it is unrealistic to think competition between them will be resolved any time soon. Accordingly, the typology presented here explores agonistic modes of participation, rather than presuming that participation should always be solidaristic. It also shows the importance of understanding the way participation is constructed when analysing the use of particular mechanisms of participation, for instance; public organisations attempts to reduce interest group manipulation of processes are commonly construed as attempts to control the process by those who do not share the Hobbesian worldview. It can also assist comparison of different participation initiatives, for instance; by increasing sensitivity to the nuance with which similar institutional forms are used for different ends - citizens' juries, for example, can and have been used as processes of arbitration and processes of knowledge transfer. In addition, a better understanding of modes of participation may assist our understanding of why some specific participation initiatives fail and others succeed. Introducing agonistic procedures into solidaristic institutional cultures may result in alienation, whereas introducing solidaristic processes into agonistic institutional cultures may result in interest group domination and processes being viewed as illegitimate.

The typology of four modes of participation - as knowledge transfer, collective decision-making, choice and voice, and arbitration - has significant advantages over existing typologies of participation, but it cannot, of course, capture all the myriad variations in participatory practice. It instead aims for parsimony - to capture the majority of variation in modes of participation in a simple, useful framework. The typology is also flexible in allowing for the exploration of hybrid forms of participation whereby elements of more than one mode are combined. Though it is beyond the scope of this article to explore them in depth, there is perhaps potential for much participatory innovation in these hybrids. The move towards thinking about state structures in terms of multi-level governance, and the difference democrat critique that there are multiple overlapping publics, not one homogeneous public, sets up multiple sites at which different modes of participation can potentially interact, and is a potential avenue for further research. 


\section{References}

Abelson, Julia, Pierre-Gerlier Forest, John Eyles, Patricia Smith, Elisabeth Martin, and Francois-Pierre Gauvin. 2003. "Deliberations about Deliberative Methods: Issues in the Design and Evaluation of Public Participation Processes." Social Science \& Medicine 57 (2): 239-51. doi:10.1016/S0277-9536(02)00343-X.

Albrow, Martin. 1970. Bureaucracy. Macmillan Student Editions. Basingstoke: Macmillan.

Arnstein, Sherry R. 1969. "A Ladder of Citizen Participation." Journal of the American Institute of Planners 35 (4): 216-24. doi:10.1080/01944366908977225.

Azzellini, Dario. 2013. "The Communal State: Communal Councils, Communes, and Workplace Democracy." NACLA Report on the Americas 46 (2): 25-30.

Baccaro, Lucio, and Konstantinos Papadakis. 2009. "The Downside of ParticipatoryDeliberative Public Administration." Socio-Economic Review 7 (2): 245-76. doi:10.1093/ser/mwn030.

Baldwin, R. 1997. "Rules, Discretion and Legitimacy." In The Policy Process: A Reader, edited by Michael Hill, 2nd ed. London: Pearson.

Barber, Michael. 2007. Instruction to Deliver: Tony Blair, Public Services and the Challenge of Achieving Targets. London: Politico's.

Barnes, Marian, Janet Newman, and Helen Sullivan. 2007. Power, Participation and Political Renewal: Case Studies in Public Participation. Bristol: Policy Press.

Bentham, Jeremy. 1789. An Introduction to the Principles of Morals and Legislation. London: Methuen, 1982.

Bingham, Lisa Blomgren, Tina Nabatchi, and Rosemary O'Leary. 2005. "The New Governance: Practices and Processes for Stakeholder and Citizen Participation in the Work of Government." Public Administration Review 65 (5): 547-58. doi:10.1111/j.1540-6210.2005.00482.x.

Bishop, Patrick, and Glyn Davis. 2002. "Mapping Public Participation in Policy Choices." Australian Journal of Public Administration 61 (1): 14-29. doi:10.1111/1467-8500.00255.

Cabinet Office. 2002. Viewfinder: A Policy Maker's Guide to Public Involvement. London: Cabinet Office.

http://www.portlandonline.com/oni/index.cfm?a=84452\&c=38802.

Cornwall, Andrea. 2008. "Unpacking 'Participation': Models, Meanings and Practices." Community Development Journal 43 (3): 269-83. doi:10.1093/cdj/bsn010.

Dean, Hartley. 2013. "The Translation of Needs into Rights: Reconceptualising Social Citizenship as a Global Phenomenon." International Journal of Social Welfare 22 (October): S32-49. doi:10.1111/ijsw.12032. 
Dean, Rikki. 2012. "Ideology and Efficacy: Exploring the Evaluation of Deliberative and Participatory Policy-Making in UK Social Policy." MSc Thesis, London: London School of Economics.

Douglas, Mary. 1970. Natural Symbols: Explorations in Cosmology. Barrie \& Rockliff: The Cresset Press.

Downs, Anthony. 1957. An Economic Theory of Democracy. Harper \& Row.

Dryzek, John S. 2000. Deliberative Democracy and beyond: Liberals, Critics, Contestations. Oxford: Oxford University Press.

. 2010. Foundations and Frontiers of Deliberative Governance. Oxford: Oxford University Press.

Dunleavy, Patrick, and Brendan O'Leary. 1987. Theories of the State: The Politics of Liberal Democracy. Basingstoke: Macmillan Education.

Elster, Jon, ed. 1998. Deliberative Democracy. Cambridge: Cambridge University Press.

Fornet-Betancourt, Raúl, Helmut Becker, Alfredo Gomez-Müller, and J D Gauthier. 1987. "The Ethic of Care for the Self as a Practice of Freedom an Interview with Michel Foucault on January 20, 1984." Philosophy \& Social Criticism 12 (2-3): 112-31. doi:10.1177/019145378701200202.

Fung, Archon. 2003. "Survey Article: Recipes for Public Spheres: Eight Institutional Design Choices and Their Consequences." Journal of Political Philosophy 11 (3): 338-67. doi:10.1111/1467-9760.00181.

. 2004. Empowered Participation: Reinventing Urban Democracy. Princeton University Press,.

Habermas, Jürgen. 1996. Between Facts and Norms: Contributions to a Discourse Theory of Law and Democracy. Translated by William Rehg. Cambridge: Polity Press.

Hague, Cliff. 1990. "The Development and Politics of Tenant Participation in British Council Housing." Housing Studies 5 (4): 242-56. doi:10.1080/02673039008720689.

Hayek, Friedrich A. von. 1960. The Constitution of Liberty. Abingdon: Routledge, 2006.

HM Government. 2010. "The Coalition: Our Programme for Government." London: Cabinet Office.

https://www.gov.uk/government/uploads/system/uploads/attachment_data/file/ 78977/coalition_programme_for_government.pdf.

HM Government, Cabinet Office. 2012. Open Public Services. White. Cab. http://files.openpublicservices.cabinetoffice.gov.uk/HMG_OpenPublicServices _web.pdf.

Hobbes, Thomas. 1651. Leviathon. London: Penguin, 1985. 
Hood, Christopher. 1998. The Art of the State: Culture, Rhetoric, and Public Management. Oxford: Clarenden Press.

Involve. 2005. People and Participation: How to Put Citizens at the Heart of Decision Making. London: Involve. http://www.epractice.eu/files/media/media1928.pdf.

Kim, Jim Yong. 2013. "Opening Address to Citizen Voices: Global Conference On Citizen Engagement For Enhanced Development Results." presented at the Citizen Voices: Global Conference On Citizen Engagement For Enhanced Development Results [World Bank], Washington DC, March 18. http://www.worldbank.org/en/news/speech/2013/03/18/citizen-voices-globalconference-on-citizen-engagement-enhanced-development-results.

Le Grand, Julian. 2003. Motivation, Agency, and Public Policy: Of Knights and Knaves, Pawns and Queens. Oxford: Oxford University Press,. 2008. The Other Invisible Hand. Princeton University Press.

Mansbridge, Jane J. 1980. Beyond Adversary Democracy. New York: Basic Books.

Martin, Graham P. 2008. “'Ordinary People Only': Knowledge, Representativeness, and the Publics of Public Participation in Healthcare." Sociology of Health \& Illness 30 (1): 35-54. doi:10.1111/j.1467-9566.2007.01027.x.

Miliband, Ed. 2014. “2014 Hugo Young Lecture.” presented at the Hugo Young Lecture, London, February 10. http://labourlist.org/2014/02/ed-milibandshugo-young-lecture-full-text/.

Mouffe, Chantal. 2000. The Democratic Paradox. London: Verso.

Osborne, David E., and Ted Gaebler. 1993. Reinventing Government: How the Entrepreneurial Spirit Is Transforming the Public Sector. Plume.

Papadopoulos, Yannis, and Philippe Warin. 2007. "Are Innovative, Participatory and Deliberative Procedures in Policy Making Democratic and Effective?" European Journal of Political Research 46 (4): 445-72. doi:10.1111/j.14756765.2007.00696.x.

Parkinson, John. 2004. "Why Deliberate? The Encounter Between Deliberation and New Public Managers." Public Administration 82 (2): 377-95. doi:10.1111/j.0033-3298.2004.00399.x.

Pateman, Carole. 1970. Participation and Democratic Theory /. Cambridge U.P.

Pearce, Jenny. 2010. Participation and Democracy in the Twenty-First Century City. Basingstoke: Palgrave Macmillan.

Plato. The Republic. Translated by Tom Griffith. Cambridge: Cambridge University Press, 2000.

Polletta, Francesca. 2014. Freedom Is an Endless Meeting: Democracy in American Social Movements. University Of Chicago Press. Accessed March 5. https://www.dawsonera.com/readonline/9780226924281.

Pretty, Jules N. 1995. "Participatory Learning for Sustainable Agriculture." World Development 23 (8): 1247-63. doi:10.1016/0305-750X(95)00046-F. 
Public Administration Select Committee. 2013. Public Engagement in Policy-Making. Second Report of Session 2013-14. London: The Stationery Office Limited: Public Adminstration Select Committee, House of Commons. http://www.parliament.uk/business/committees/committees-a-z/commonsselect/public-administration-select-committee/news/public-engagement-report/.

Rousseau, Jean-Jacques. 1762. The Social Contract. Translated by Maurice Cranston. London: Penguin, 1968.

Rowe, Gene, and Lynn J. Frewer. 2005. "A Typology of Public Engagement Mechanisms." Science, Technology \& Human Values 30 (2): 251-90. doi:10.1177/0162243904271724.

Schmidt, Vivien A. 2008. "Discursive Institutionalism: The Explanatory Power of Ideas and Discourse." Annual Review of Political Science 11 (1): 303-26. doi:10.1146/annurev.polisci.11.060606.135342.

Schumpeter, Joseph A. 1976. Capitalism, Socialism and Democracy. 5th ed /. Routledge,.

Shaw, Tamsin. 2008. "Max Weber on Democracy: Can the People Have Political Power in Modern States?" Constellations 15 (1): 33-45. doi:10.1111/j.14678675.2008.00472.x.

Sintomer, Yves, Carsten Herzberg and Anja Roecke. 2008. "Participatory Budgeting in Europe: Potentials and Challenges." International Journal of Urban and Regional Research 32 (1): 164-178. doi: 10.1111/j.1468-2427.2008.00777.x.

Smith, Adam. 1776. The Wealth of Nations - Books I-III. London: Penguin, 1999.

Smith, Graham. 2005. "Beyond the Ballot: 57 Democratic Innovations from around the World.” http://eprints.soton.ac.uk/34527/.

Sørensen, Eva, and Jacob Torfing. 2005. "The Democratic Anchorage of Governance Networks." Scandinavian Political Studies $28 \quad$ (3): 195-218. doi:10.1111/j.1467-9477.2005.00129.x.

Tritter, Jonathan Quetzal, and Alison McCallum. 2006. "The Snakes and Ladders of User Involvement: Moving beyond Arnstein." Health Policy 76 (2): 156-68. doi:10.1016/j.healthpol.2005.05.008.

Wainwright, Hilary. 2003. Reclaim the State: Adventures in Popular Democracy. London: Verso.

Webb, Sidney, and Beatrice Webb. 1920. A Constitution for the Socialist Commonwealth of Great Britain. Cambridge: Cambridge University Press for the London School of Economics and Political Science, 1975.

Weber, Max. 1922. Economy and Society: An Outline of Interpretive Sociology. London: University of California Press, 1978.

White, Sarah C. 1996. "Depoliticising Development: The Uses and Abuses of Participation." Development in Practice 6 (1): 6-15. doi:10.1080/0961452961000157564 